\title{
Imagining Surveillance: Utopian Visions and Surveillance Studies.
}

\author{
Peter Marks ${ }^{1}$
}

\begin{abstract}
This paper considers the role of utopian (and dystopian) visions in the study of surveillance, arguing that the fiction in written or filmic form offers much that is stimulating to surveillance studies. The article focuses on four recent examples of such texts: The Truman Show, Gattaca, Code 46 and The Traveller. It argues that all present differing visions that move far beyond the nightmare of George Orwell (or indeed Michel Foucault) to present a more nuanced view
\end{abstract}

\section{Introduction}

Imagine a world where all the cities are identical, where people dress uniformly, where you need written permission to travel beyond your immediate environs (and where failure to gain permission leads to enslavement), where you are obliged to travel in groups, where house doors operate automatically so that nothing is private or exclusive, where there are no hiding places outside the home, no spots for secret meetings, and where inhabitants live in full view of each other. Such a place conjures up associations with Kafka and Orwell, a nightmarish version of what David Lyon has labelled contemporary 'surveillance society' (Lyon, 1994, 2001). But the elements catalogued here were first published in 1516, in Thomas More's genre-establishing classic, Utopia. Surveillance today is a powerful, pervasive, multi-dimensional social fact, but fictional works from More through Orwell's Nineteen Eighty-Four and beyond have long provided vivid, provocative and critically informed accounts of surveillance practices and trends. In the current environment, where rapid and massive changes in surveillance technologies and imperatives demand increasing degrees of speculation, fictional works provide stimulating points of reference for surveillance scholars. This article concentrates on the utopian genre (one that incorporates the sub genre of the dystopia), arguing for its longestablished concern with surveillance matters. But in the bulk of the article I deal primarily with recent reworkings of these concerns in a novel and three films, works that, while drawing from the past, assess the current state of affairs, and speculate on the brave new world emerging.

These imaginative projections cover a range of surveillance practices and effects, and it is

1Department of English, University of Sydney, Australia. mailto:peter.marks@arts.usyd.edu.au 
useful at this early stage to sketch in some outlines. Peter Weir's highly successful film, The Truman Show (1998) depicts and assesses the impact of reality television on notions of privacy and identity, adapting Orwell's account of constant visual scrutiny by fusing it with the contemporary adulation of celebrity. In The Truman Show, surveillance has morphed into entertainment. Andrew Niccol's Gattaca (1998) examines a near future in which genetic testing and embryo screening and manipulation have created a society organised on the basis of genetic discrimination, a world in which the genetically elite have access to a world of material plenty and prestigious jobs, while those deemed genetically inferior endure menial work and social prejudice. As its title suggests (46 chromosomes make up our DNA), Michael Winterbottom's stimulating, if neglected film, Code 46 (2003), also deals with genetic discrimination. But here the genetic screening and accompanying sanctions are required because advances in fertility treatments have increased the chances of genetically incestuous relationships. Code 46 also investigates beyond mere genetic surveillance, for in this projected world passes are required to gain access to the materially wealthy cities. Those denied a pass are forced to live outside the cities' borders in dystopian conditions akin to the current third world. The most recent of the texts examined here is John Twelve Hawk's best-selling novel, The Traveller (2005), which posits a present or near future in which $99 \%$ of the population live unwittingly or contentedly on a surveillance network called the Grid, overseen by an amorphous authority known as the Vast Machine. Blending a sound awareness of surveillance theory with Da Vinci Code-like conspiracy theories, The Traveller proposes that a sinister and secret group, The Brethren, aims to bring the world under the control of a Virtual Panopticon, modelled on the ideas of Jeremy Bentham. While it never aspires to being great literature, The Traveller's success suggests an ongoing interaction between surveillance and the public imagination, and emphasises the ways in which public concerns and awareness can be reflected in and fashioned by fictional novels and films.

\section{The Case For and Against Utopias}

Before analysing the individual texts in more detail, we need to consider their generic relationship and deal with some of the complexities and problems in defining and interpreting them as utopias. Surveillance theorists and social researchers have long recognised the value of such texts. Twenty years ago, in Visions of Social Control, Stanley Cohen placed his arguments in 'the wider context of utopian and dystopian visions,' explaining that 'social-control ideology is deeply embedded in these more general predictions, fantasies, visions and expectations' (Cohen, 1985: 199). A pioneering figure in surveillance studies, James Rule, had earlier acknowledged the importance of Orwell's Nineteen Eighty-Four in his own and the public's understanding of surveillance (Rule, 1973: 15). The leading contemporary authority, David Lyon, also acknowledges a debt to Orwell (Lyon, 1994: 57). More recently still, Benjamin Goold admits that '[1] ooking back over the discourse of surveillance and technology over the last fifty years it is difficult to overestimate the impact of Orwell's novel. . . . on popular and academic imaginations' (Goold, 2004: 208). Even more influential for surveillance theorists has been Michel's Foucault's dystopian reworking of Bentham's utopian panopticon in such generative studies as Discipline and Punish and Birth of The Clinic.

Yet, the utility of such texts does not immunise them from criticism. Lyon warns that 
neither Orwell's nor Foucault's work,

should be thought of as the only, let alone the best, images for yielding clues about surveillance. Powerful metaphors lie relatively unexamined in various films as well as novels such as Franz Kafka's The Castle or Margaret Atwood's The Handmaid's Tale (Lyon, 1994: 78).

Significantly, in terms of the argument presented here, both of these texts are included in M.Keith Booker's authoritative Dystopian Literature: A Theory and Research Guide (1994). Goold makes a more general point, noting that while Orwell and Foucault 'have been instrumental in shaping the way many criminologists and social theorists now think about questions of surveillance and its role in contemporary society,' unless researchers focus on actual social institutions like the police, 'the theoretical literature of social control will become increasingly divorced from reality' (Goold, 2004: 212). Where Lyon argues for detailed analysis of examples beyond the usual suspects, something this article undertakes, Goold strongly implies that an important border needs to be patrolled between social reality on one side and fictional representations of society on the other. I would argue that while surveillance scholars (especially social scientists) quite properly investigate the social world as objectively as possible, much can still be learnt from the more subjective and speculative realms of fictional texts. The philosopher Martha Nussbaum declares that literature generally (and, I would add, films) calls 'forth certain sorts of practical activity in the reader that can be invoked in no other way,' adding that 'we need a story of a certain kind, with characters of a certain type, if our own sense of life and of value is to be called forth in the way most appropriate for practical reflection' (Nussbaum, 1990: 228-9). Richard Rorty also argues the importance of this empathetic process, one of "coming to see other human beings as "one of us". Rorty asserts that fiction can give 'us the details of what sorts of cruelty we are capable of'. This, for him, explains 'why the novel, the movie, and the TV program have, gradually but steadily, replaced the sermon and the treatise as the principle vehicles for moral change and progress' (Rorty, 1989: xvi). Maureen Whitebrook provides a useful summary of the possibilities opened up by novels (and, again, I would argue, by many films): 'Novels are particularly good at showing the necessity of making choices, the psychological pressures on the individuals who face them, the moral dilemmas involved and the consequences of choice, the political effects of reactions to those problems' (Whitebrook, 1996: 47). Taken together, Nussbaum, Rorty and Whitebrook provide reasons why a consideration of the shaping influence fiction has on people's perceptions might be valuable in understanding the ways they conceive of and react to surveillance. Fiction generally can have an impact on individual and social thinking and the action resulting from that thought. Utopian fiction particularly retains a didactic purpose along with its speculative approach, elements that challenge the thinking of readers and viewers, and potentially provoke them to practical action.

Lyon suggests another argument against dystopias specifically, asserting that while dystopian visions

have the virtue of directing our attention to the negative, constraining, and unjust aspects of surveillance. . . their disadvantage is that they exaggerate the negative by only seeing one side of surveillance, 
promoting pessimism about whether negative traits can be countered, and fail to offer any indication as to what the content of the alternative might be. (Lyon, 1994: 204)

At one level the charge that dystopian texts tend to the negative is tautologous, given that the term 'dystopia' defines texts that present undesirable worlds. But the argument also involves a reductive conception of dystopias, for the distinction between dystopias and utopias is not simple or clear. To take an famous example: while most of the characters in Huxley's Brave New World believe themselves to inhabit a utopia of instant and endless gratification, particular characters vigorously reject the dominant view, seeing themselves as living a dystopian existence. Equally importantly, no matter what the protagonists think, readers can adopt a range of positions, not all of them as radically antagonistic as that of John Savage. Indeed, Huxley adds a paradoxical epigraph to the novel from Nicolas Berdiaeff that asks whether, in an age when utopias seem possible, readers might want something non-utopian, less perfect, but more free. Huxley challenges us to think not only about the shape and content of utopias, but also about their very desirability.

Gregory Claeys and Lyman Tower Sargent map out the complex relationship between utopias and dystopias in the introduction to The Utopian Reader (Claeys and Sargent, 1999: 1-5), where the terms appear in list of categories under the umbrella term of Utopianism, defined as 'social dreaming'. The Utopia generally is named as 'a nonexistent society described in detail and normally located in time and space,' and then is divided more specifically into the 'Eutopia or positive utopia', intended to be 'considerably better than the society in which the reader lived' (1) and the 'Dystopia or negative utopia - a utopia that the author intended a contemporaneous reader to view as considerably worse than the society the reader now lived' (2). Claeys and Sargent also distinguish the 'Utopian satire,' meant to be 'a criticism of the existing society,' the Antiutopia, seen as 'a criticism of utopianism or of some particular eutopia,' and the Critical Utopia, which, though 'better than contemporary society [has] difficult problems that the described society may or may not be able to solve, and which takes a critical view of the utopian genre' (2). More recently still, Sargent has added another term, Critical Dystopia, for a text that shares the main characteristics of the dystopia but 'that normally includes at least one eutopian enclave or holds hope that the dystopia can be overcome and replaced with a utopia' (Sargent, 2001: 222). These discriminations indicate the captivating variety of texts produced under the banner of 'social dreaming' (which can, of course, also include nightmares). They also underline the importance of reader activity, including, for example, the fact that the readers can interpret the text against the grain of its author's intention. As with all cultural texts, a multiplicity of interpretations is possible. And, as Claeys and Sargent recognise, 'fashions change,' so that 'most sixteenth-century eutopias horrify today's readers. . . .[and] a sixteenth century reader would consider most twentieth-century eutopias as dys-topias [sic] worthy of being burnt as works of the devil' (1). Utopian texts have a shelf-life well beyond their initial appearance. Collectively they offer us a vivid and informative history of surveillance concerns and predictions over the centuries.

The interpretive activity of readers or viewers in different historical and social circumstances, then, destabilises simple dichotomies between utopias and dystopias as 
purely good and bad worlds. Utopian theorists argue that this destabilising process is activated by what might be called the genre's DNA. Darko Suvin, one of the most influential utopian and science fiction scholars, argues that these are genres "whose necessary and sufficient conditions are the presence and interaction of estrangement and cognition, and whose main formal device is an imaginative framework alternative to the author's empirical environment' (Suvin, 1979: 7-8). Somewhat confusingly, Suvin folds utopias with the embrace of science fiction, but utopian scholars have taken up and adapted his key notion that the presentation to the reader or viewer of an alternative world based on different principles from their own world (what Suvin terms the 'novum') produces a form of cognitive estrangement that opens up new thoughts and possibilities. For Tom Moylan, the utopia provides a 'manifesto of otherness' (Moylan, 1986: 37) that generates new ways of thinking about and acting upon contemporary society. He writes that 'in the estranged vision of another world lie the seeds for changing the present society' (35). Fredric Jameson reinforces this sense of utopias as heuristic tools for creating social debate, judging it useful to understand utopian discourse generally as 'an object of meditation. . . whose function is to provoke a fruitful bewilderment and to jar the mind into some heightened but unconceptualisable consciousness of its own powers, functions, aims, and structural limits' (Jameson, 1988: 87-88).

While the arguments of Suvin, Moylan and Jameson for fruitful bewilderment might seem to apply readily to positive worlds, Lyman Tower Sargent's delineation of the 'critical dystopia' indicates that the contents of the text, positive or negative, merely provide a starting point for active reader interpretation. From Sargent's perspective, Lyon's argument that dystopias depict only the negative side of surveillance does not take into account the productive cognitive estrangement that such a representation might provoke. For some readers or viewers a dystopian account might promote pessimism, but for others the same narrative and images might spark a call to action, or engender a healthy scepticism about arguments for the extension of surveillance. Which, of course, has been the case with Nineteen Eighty-Four, one of the most negative depictions of a total surveillance society, but still a touchstone for notions of resistance. Dystopias might not provide alternatives within their narratives, but that need not be a fault if, as Nussbaum suggests, they instigate reflection and action in their readers. Baccolini and Moylan argue that most dystopias focus 'on a character who questions the dystopian society', which they see as part of 'a deeper and more totalizing agenda in the dystopian form insofar as the text is built around the construction of a narrative of the hegemonic order and a counter narrative of resistance (Baccolini and Moylan, 2003: 5). The dystopia, they contend, generates a 'critical encounter that ensues when the citizen [in such a text] confronts, or is confronted by, the contradictions of the society' (2003: 6). Rather than being static, negative texts that promote pessimism and shut down productive thinking in audiences, scholars of utopianism contend that dystopias activate thought and action.

\section{The Truman Show}

Having argued the case for the overarching utopian genre, I now want to look more closely at recent works that illuminate new areas of surveillance and that dissect new trends, problems and possibilities. Peter Weir's The Truman Show offers an engaging and provocative account of modern celebrity culture, with its belief that the unscreened life is not worth living. Reflecting on the emerging (but at that point not ubiquitous) genre of reality television, The Truman Show examines such important and established 
surveillance concepts as identity, privacy, the organization of social space and practices, and the utilisation of personal information for control. Connections to the telescreens of Nineteen Eighty-Four seem obvious, and Truman's defiant cry as he breaks free, 'You never had a camera in my head,' clearly echoes Julia's 'They can't get inside you' (Orwell, 1997: 174). As Winston Smith finds out, however, in Oceania they can. 'The Truman Show' as a television show also seems to invert to the Orwellian principle that being under constant scrutiny is the ultimate index of oppression. By contrast, Truman unknowingly has attained that most sought-after of contemporary prizes, television stardom. But in fact the principle holds true, for once Truman recognises that he is under scrutiny by the cameras and characters surrounding him, he starts to resist in ways reminiscent of Winston Smith, and of characters in dystopias generally. What initially had seemed (for the film audience) an amusing ruse rapidly descends into the televisual equivalent of a totalitarian state, with the show's director Christo a cross between God, Big Brother and Walt Disney.

As well as assessing the protagonist and the show, supposedly based on Truman's life but in fact constructing a commodity-friendly persona, the film explores an important third force, the television audience. If we adopt the Orwellian formulation, the show's production staff would approximate the Thought Police. But the film also depicts the show's viewers as equally complicit in Truman's oppression. The majority do not see themselves in these terms, although the subversive 'Free Truman' movement indicates that some viewers do recognise the show for the dystopia it is. Even within the show's audience, then, there are dissenters. It is important to keep in mind the distinction between the audience watching the 'The Truman Show' on television and those watching The Truman Show in the cinema, because this latter group is likely to interpret the show almost immediately as a dystopia, whereas most of the television audience treats the show as close to a utopia. This tension between utopian and dystopian possibilities and imperatives signals The Truman Show as a critical dystopia, one that offers a compelling account of a seductive dystopian prison, and a freer, and therefore utopian world beyond.

The role of the television audience in the surveillance regime constantly scrutinising Truman constitutes one of the more disturbing and illuminating aspects of the film's thrust, although the satirical bite is somewhat weakened by a concentration on the narcissistic and megalomanic Christo. Yet, as we see, once Truman's life-threatening attempts to escape gain audience empathy, the show cannot survive without its viewers. Christo's power is a function of, and therefore dependent on, commercial imperatives. So too is Truman's identity, or rather the identity created for him in order to sell products. Surveillance fuses with commodity culture. Scrutiny of personal data marks one of the defining elements in surveillance, modern or otherwise, but the film shows how information, real and artificial, might be fashioned into a personal identity and a social reality that the individual (in this case Truman) comes to accept as real, at least initially. The truth that characters and narratives in Truman's life have been adulterated to satisfy audience ratings underlines the pernicious part played by what appears to be a docile audience merrily following Truman's televised life. In fact, his 'life' and 'identity' are products of their continued viewing; without them, 'Truman Burbank' would not exist. This reality, that that television audience as much as the television channel traps Truman in a dystopia gets transmitted forcefully to the film audience. 
Such an insight has social relevance beyond its representation in fiction. Audience power linked with surveillance has been replicated in actual reality shows such as 'Big Brother,' where levels of danger, raunchiness and absurdity have been increased to satisfy or create audience demand. The television audience in The Truman Show, like those watching reality shows at home (even, ironically, those watching 'Big Brother'), would not doubt reject any links to Orwell, but it seems undeniable that collectively they play a powerful part in contemporary regimes of surveillance now accessible from home. These might include, apart from ubiquitous reality shows, funniest home movie shows (where viewers send in their private video tapes), to the innumerable licit and illicit webcam sites and chat rooms. Many of these sites are benign and indeed educational (such as those allowing people to view images from space exploration) but all underline the contemporary truth that in part surveillance has been refashioned to provide revenue-raising entertainment. And certain important forms of information: recent war footage has allowed viewers access to live footage of military patrols, or missiles zeroing in on their targets; Colin Powell's use of surveillance photos in his United Nations address proved important in making the psychological as well as military case for the war Iraq. Images from various forms of official and unofficial surveillance are the stuff of the prime time entertainment, as well as of news and current affairs. In the half century since Orwell, Big Brother has become big business.

The Truman Show provides a test case for the complex relationships between utopias and dystopias. Truman's hometown of Seahaven seems to replicate a saccharine vision of 1950s American suburbia. In a peculiarly postmodern twist, however, the film set is, in fact, the real town of Seaside, Florida, used to represent a false, nostalgic utopia. Given the commercial underpinnings of the show, this choice of location fits both the narrative and audience's expectations of the residential utopia a character like Truman should live in. For Truman, too, in the opening section of the film, Seahaven functions as a comforting and idyllic home. But as he comes to comprehend the fraud being played on him, the idyllic space quickly becomes totalitarian and dystopian. While the television audience also slowly comes to that conclusion, those watching The Truman Show film are less likely to treat Seahaven as anything other than a perverse and oppressive façade. These diverse responses receive an early test when a stage light falls from the fake sky. The light baffles Truman, who is gulled into believing that it fell from a passing plane. The television audience no doubt writes it off as a production glitch. The film audience, by contrast, most likely reads it as indicative of the artificiality of Truman's world. Three levels of interpreters read the same space and events in markedly different ways, although, as the film progresses, the interpretive move from utopia to dystopia becomes more insistent for all three. Ironically, when Truman escapes, he gives up the false utopia of Seahaven for the mean streets that surround the film set, but this rejection of Seahaven signals his choice of freedom and uncertainty over numbing security. John Savage in Brave New World argues the same case before succumbing to suicide, and both forms of rejection follow the generic pattern of the critical dystopia. The film's ending, though, focuses not on Truman's freedom but on the television audience, initially enjoying the vicarious liberation of his rebellion against the system, but then immediately looking for new sources of entertainment. Still trapped in the dystopian world of reality television viewing, they are held up to the film audience for critical assessment. But while the film makes its satirical point about the television audience, the real thrust of that point 
is lost unless those watching The Truman Show film recognise themselves as equally complicit once they return home to their own televisions, to their own private surveillance worlds.

\section{Gattaca}

In the same year that Peter Weir provided an often comic, if still disturbing, account of surveillance as entertainment, Andrew Niccol's Gattaca offered a far grimmer vision of a future in which genetic screening had created a rigidly hierarchical society based on genetic discrimination. Using predictions based on blood samples taken soon after birth, children are divided into the genetically superior 'Valids,' and the inferior 'Invalids' or 'Degenerates' (pronounced 'De-gene-rates'). This profiling is reinforced by regular genetic tests, so that the protagonist, an Invalid named Vincent Freeman, ruefully notes as he fails another job interview, 'My real resume was in my cells'. It is officially illegal, he knows, 'to discriminate. "Genoism" it's called. But no one takes the law seriously'. His own genetic deficiencies deny him access to the exclusive space programme he dreams of joining, run by the Gattaca Aeroscape Corporation. Unable to enter Gattaca, except as a cleaner, Vincent embarks on a highly illegal subterfuge in which he buys the genetic identity of a paralysed Valid, Jerome Morrow. After a physical makeover, so that he roughly approximates Jerome's outward appearance (including the painful extension of his too-short legs) Vincent goes for an interview at Gattaca, where he is required to supply a sample of his urine. He uses Jerome's, and immediately is offered a job. Puzzled by his success, he is told that the urine sample is the interview. Although he needs urine, blood, skin and hair provided by Jerome to survive the regular tests at Gattaca, Vincent succeeds by his own will and effort in winning a place on a coveted space flight to one of Jupiter's moons. His subversive feat confirms the film's tagline, 'There is no gene for the human spirit'. Where Truman escapes the surveillance regime of the studio, Vincent flies into space, literally escaping the dystopian surveillance regime of the Corporation for the utopia of space exploration.

Although the film ends triumphantly for Vincent, Gattaca as a whole presents a harsh critique of the society that institutes and organises itself in terms of genetic discrimination. Jennifer Poudrier uses Gattaca as an introductory example in her study of 'epidemiological surveillance,' noting rather dismissively that 'the scenario is merely fiction and perhaps only represents our deepest fears regarding the progress of genetic information and technology' (Poudrier, 2003: 111). Nevertheless, the combination of fiction and fear links with the definition of utopianism as imaginative social dreaming. And Poudrier balances her faint praise with the realisation that 'many current aspirations surrounding the use of genetic information present a disturbingly similar scenario' (111). Gattaca provides something than a mere example of a current trend, however, for, in a classic dystopian manoeuvre, it provides a counter narrative of resistance to genetic discrimination, not merely a fictionalised account of it. Vincent's ultimate success, based on determination, ingenuity and a desire to rise above the blueprint his genes supposedly provide, clearly undermines the logic and ideology of the genetic profiling instituted by the state and the corporation.

The film begins in a flashback, before the move to universal genetic profiling, with the adult Vincent commenting on his own birth: 'They used to say that a child conceived in love has a greater chance of happiness. They don't say that any more'. Vincent's blood 
test at birth predicts with a high (but not total) level of probability that his life expectancy will be only 30.2 years, the likely cause of his death being from heart failure. As a result of this, he notes, 'I came to see myself as others saw me-chronically ill'. Worse, the information encoded in his genes means that social prejudices will forever limit his chances in life. In this world, genes are destiny. The discrimination even extends to his parents, who, in order to ensure that their second child will not be genetically deficient, have a set of their fertilised eggs screened and manipulated to remove imperfections. By the time of this second child (who, in another signal of discrimination is named Anton after his father) such genetic tampering has become so common that their geneticist tells them that has 'taken the liberty of eradicating any potentially prejudicial conditions' including alcoholism, premature baldness and myopia, obesity and a propensity to violence. Vincent's parents too invoke their own prejudices, stipulating that they want a boy, one with hazel eyes, dark hair and fair skin. Niccol subtly exposes the hypocrisy, bigotry and implications of these choices: Vincent's father Anton wears glasses, and the geneticist is a balding African-American. Anton junior, then, literally embodies the rejection of elements that have made up previous generations. And whereas Vincent's genetic makeup denies him opportunities, his younger brother's screened and manufactured genes ensure that prejudice works in his favour. The screening of genetic codes in Gattaca takes surveillance into the prenatal zone.

Gattaca necessarily prompts comparisons with the most famous dystopia based on genetic manipulation, Brave New World. But whereas Huxley projects a world he initially thought would be centuries away, Niccol uses processes and trends that, as Poudrier suggests, either exist already or are plausible in 'The Not-too Distant Future' the film depicts. With genetics the essential code for social sorting (the letters that make up the name Gattaca come from the first letters of the four bases that make up DNA) body surveillance is the norm. But, because the social sorting takes place at the genetic level, physical appearance is less an identity marker than samples of blood or urine. In Huxley's world, genetics is a matter of test tubes and chemicals, and while occasionally there are mistakes, no one pretends to be other than who they are. Gattaca, by contrast, explores ways in which surveillance systems can be overridden or subverted. While Vincent may be what is termed a 'borrowed ladder' in using Jerome's genetic identifiers, he is not unique, and uses a black market middleman who extracts a hefty fee for his services. As the middleman recognises, Vincent and others like him are desperate to overcome the surveillance regime, and the product he sells (Jerome's genetic identity) is a valuable commodity: 'you could go anywhere with this guy's helix tucked under your arm'. Because of the type of screening taking place, what lies beneath the surface supersedes whatever capacities a person might enjoy. It even overrides what they look like, for in a variety of screening processes Vincent passes for Jerome Morrow even when photographs clearly indicate a recognisable difference in appearance. As Jerome observes, as long as Vincent has his blood samples, 'they don't see you, they see me'. The body, and identity itself, is 'read' and valued primarily at the genetic level.

The Truman Show linked surveillance to commerce by virtue of the fact that the show itself was a profit-making enterprise. In Gattaca, the trade in genes creates a lucrative black market, the middleman who connects Vincent to Jerome claiming ' $25 \%$ of everything you make'. Part of the transaction involves Vincent subsidising Jerome's lifestyle; though physically disabled, Jerome also recognises that since society only 
scrutinises genes, his are a valuable commodity. Once accepted in the Gattaca Corporation, Vincent himself lives a materially rich life, far removed from the economic deprivations of the genetically inferior from which he had come. In a telling scene, he comes across his former boss, still the head cleaner at Gattaca, who fails to recognise him, accepting him as the Jerome Morrow of his identity tag. While the state does use genetic information to track and control the population in general, a primary exploiter of genetic surveillance is the corporation. The aerospace industry in Gattaca replaces the television studio of The Truman Show. As Gattaca's Director explains to a detective investigating a murder within its walls, the corporation only accepts the best of the Valids, adding tartly that in the past it would 'occasionally accept candidates with minor shortcomings, but nothing that would prohibit someone from a field such as law enforcement, for example'. As the detective's pained response makes clear, although he is a Valid, he is not in the top echelon. A genetic hierarchy exists even among the elite. The fact that the detective is Vincent's brother Anton adds a particular resonance to the dismissive comment. But, the Director adds, "now there are enough of the right kind of people to warrant a new measuring stick. Bodies with minds to match, essential as we push out further and further'. Genetic discrimination ensures the viability and continued expansion of Gattaca's commercial venture in space. The corporation's utopian project, it would argue, could only be achieved by genetic surveillance and the discrimination that sorts out the best candidates.

But while the ideal of genetic discrimination underpins the utopian dreams of the Director, the film repeatedly calls into question the prevailing ideology of this surveillance regime. A variety of characters rise above, fall short of, or betray their supposed genetic destiny. Chief amongst them, of course, is Vincent, but even the former champion swimmer Jerome, whose superior genes should have ensured success, gets beaten in competition, something he cannot accept: 'Silver. Jerome Morrow was never meant to be one step down on the podium. With all I had going for me I was still second best. Me.' We can assume that great genes and arrogance alone are no match for the effort Vincent puts in. Other Valid characters are also deficient or odd in terms of the genetic ideal. Vincent's co-worker and romantic interest Irene has the same heart deficiency as he does, and the son of the lab worker, Lamarr, who tests Vincent's urine and blood samples, is also less than perfect. Consequently, both are denied the chance to fly in space. Once romantically linked, Vincent and Irene attend a concert where a pianist with twelve fingers mesmerises the audience. The odd can excel; and the superior can fall. Just as, in Jerome's case, superior genes do not ensure against fate, they also are no guarantee of superior morals or actions. To emphasise the generic counter narrative, not all Gattaca employees accept its ideology blindly. Irene eventually finds out Vincent's true identity, but accepts him for what he is. And in a final twist, when Vincent assumes that Lamarr has discovered his real identity, the technician reveals that he has always known that Vincent was not Jerome. Because his own son has been discriminated against by Gattaca, Lamarr has secretly admired Vincent's tenacious fight against institutional prejudice and has subverted the system in order to help him. Ultimately, then, the film argues for genetic diversity and against notions of purity and hierarchy that genetic surveillance might impose.

Code 46

Michael Winterbottom's Code 46 also addresses the interplay of surveillance and 
genetics, but provides a more subtle and complex reading of the problems and possibilities. Where Gattaca posits a world organised primarily on the basis of genetic apartheid, Code 46 deals with the consequences of fertility practices already available or on the verge of being perfected. In the near future setting of the film, the widespread use of invitro fertilisation, cloning and embryo splitting has increased the chances that incestuous relationships (knowingly or unknowingly) might take place. In order to counter this dilemma, Code 46, one of a series of regulatory codes, requires that: "All prospective parents should be genetically screened before conception. If they have $100 \%, 50 \%$ or $25 \%$ genetic identity, they are not permitted to conceive.' Those who knowingly disregard the code risk harsh sanctions, including expulsion from the materially wealthy utopian cities to the dystopian environment beyond. This division of the globe into utopian and dystopian spaces requires an older form of surveillance, that linked to passports and passes, or 'papelles', in the polyglot language of the future. As John Torpey convincingly documents in The Invention of the Passport (2000), the issuing and administration of such passes has a long and complicated history, one that determines identity and authenticity both within and between states. In the global world of Code 46, borders are transit points at which those outside argue and connive to gain entrance to the utopian spaces, while those inside dread the possibility of being ostracised to the dystopian outer world. Furthermore, those 'inside' are also subject to restriction about where, and for how long, they can remain in restricted locations. Papelles provide the means to travel, but they are programmed to allow only access for designated periods; when that time expires, it is possible to be trapped in the space you currently inhabit, unable to move without authorisation. Thus, the pass system, while enabling for those with the correct documents, also functions as a tracking device, and activates a holding system. In Torpey's term, it can 'embrace' citizens, especially those who do not want that embrace.

While not without its dramatic problems, the film's overlaying of different surveillance systems signals it as a potentially rich source for analysis. As we should by now expect, the future world incorporates a counter narrative, in which the manufacture and sale of false papelles constitutes a subversion of the surveillance system and allows access to the utopian cities, or to restricted areas, for those otherwise excluded. William Geld, a top investigative officer, is sent to track down those responsible for manufacturing the fakes. Armed with an empathy virus that allows him to read the minds of those he encounters (in a sense, another type of surveillance) he discovers the culprit, Maria Gonzalez, but finds that he has fallen in love with her. He incriminates another worker, who then is expelled from the utopian world to the deprived world beyond the regulatory borders. But in his efforts to protect Maria from one surveillance mechanism and consummate an affair (he is married) he comes to realise that they are genetically linked. He was an invitro birth and she is a clone of his mother, so that their relationship knowingly violates Code 46 . When she falls pregnant, the state arrests her, aborts her baby under the provisions of Code 46, and wipes her memory, so that she cannot recall her affair with him. It then infects her with a virus that will cause her to convulse if she comes into sexual contact with Geld. Despite this, they manage to escape beyond the border and enjoy a brief romance, before a road accident causes them to be arrested. He is re-integrated to the utopian world, his memory of the affair erased, while she is banished forever to the dystopian lands, wandering at the end of the film in the threadbare clothes of a third world woman.

This admittedly truncated version of a complicated plot gives some indication of Code 
46's complex take on surveillance. Winterbottom provocatively interleaves genetic and border scrutiny, exploring how regimes of power invoke different overlapping forms of surveillance as means of control. The viewer of the film, tossed into a future environment perplexingly different from today, but containing contemporary resonances, confronts the sort of cognitive estrangement Suvin associates with utopias generally. Additionally, the film's rather ambivalent division of utopian and dystopian spaces makes it unclear what constitutes good and bad places. When William gives a false papelle to a vendor who had charmed him at the border and begged for assistance, we accept his altruism as well intentioned. Yet the utopian habitat now opened up for the vendor remains a vigorously monitored space in which various forms of identity recognition system and passes scrutinise and shepherd those enjoying its sensual delights. Indeed, William and Maria's most romantic moments occur outside its utopian boundaries. Rather than romanticise this space, though, Code 46 makes it clear that the majority of this environment is miserably poor as well as dangerous to the point of being lethal. Neither zone is fully utopian or dystopian. The treatment metered out to Maria, whether the forced abortion, the memory wipe or the final expulsion, all speak to a brutal regime forcefully imposing itself upon dissident citizens. And the reintegration of William into the purported utopian world signals the system's dubious morality. The viewer ultimately is more likely to sympathise with Maria's suffering in dystopia than William's resumption of his earlier life in utopia, despite his acknowledged role in resisting and subverting the state system. In exploring the surveillance systems that maintain order and underpin the materialist wealth of the utopian space, as well as punishing those who threaten the state's stability, Code 46 prompts its viewers to critically assess the competing values justifying surveillance in an environment complex and contradictory enough to parallel our own.

\section{The Traveller}

Despite its stimulating take on surveillance, Code 46 did not enjoy great commercial success. This sharply distinguishes it from John Twelve Hawks' best selling novel, The Traveller, published in 2005 and already optioned for film adaptation. The success of The Traveller derives in large measure from its informed integration of public concerns about surveillance and a plot suggesting dark forces lurking behind the façade of social order. A hybrid that splices together Jeremy Bentham, The Matrix and The Da Vinci Code, The Traveller depicts a relatively contemporaneous world in which $99 \%$ of the population live happy lives plugged into the prevailing social system, named the Grid. Readers are told that

If you looked at modern civilisation in a certain way, it seemed like every commercial enterprise or government program was part of an enormous grid. The different lines and spaces could track you down and fix your location; they could find out almost everything about you (Hawks, 2005: 43).

The overwhelming mass of the population happily connect themselves to the Grid, which is administered by a force called the Vast Machine, accepting the material and personal benefits flowing from connection. A small group of characters, however, consciously shun the Grid, preferring to live alternative lives within the urban environment or outside in secluded quasi-utopian communities. These dissenters attempt to evade a variety of standard surveillance measures including forms of facial recognition, the tracking of card- 
based information, surveillance cameras, GPS location devices, ID chips in passports, and the monitoring of phone and computer traffic. Clearly a student of recent surveillance theory and practices, Hawks fashions a world in which these overlapping systems maintain what to most citizens is a benign or largely unrecognised surveillance network which they accept as the price of security, convenience and stability.

As with other dystopias, readers quickly recognise that social proclamations of security, convenience and stability need to be treated sceptically. But in The Traveller the overt surveillance regime is utilised and extended by a more sinister force, akin to Dan Brown's Opus Dei. In this novel they call themselves The Brethren, although their enemies know them as The Tabula, derives from the phrase 'tabula rasa', Latin for 'blank slate'. In one of many rather laboured passages where key concepts are explained, the reader learns that 'The Tabula think that the human mind is a blank slate when you're born. That means that men in power can fill your brain with selected information' (151). While purportedly existing for centuries, in the modern era The Tabula rejects the historically successful models of totalitarian control practiced by Hitler and Stalin for 'the more sophisticated Panopticon system developed by the eighteenth-century British philosopher Jeremy Bentham.' As one of the high-ranking Tabula functionaries explains, 'You don't need to watch everyone if everyone believes they're being watched,' adding that 'Punishment is necessary, but the inevitability of punishment has to be programmed into the brain' (132).

For surveillance theorists, this thumbnail guide to panopticism remains just that, a gloss on something far more complex. But for the wider public who might not have heard of Bentham, Foucault (who does not rate a mention) or panopticism, The Traveller introduces some emerging surveillance technologies, practices and theories. Because it is set roughly in the recognisable present, The Traveller seems less overtly a dystopia than those texts set in the future, or in a fantastic place. It might be deemed a thriller with dystopian aspects. But in fact The Traveller exhibits most of the generic traits of the dystopia: a hegemonic order; a narrative of resistance, and the activation of cognitive estrangement in the reader. Estrangement derives from the fact that while the world depicted is very much our own, the underlying forces said to be at play force the reader to reflect on aspects of the social order they have either taken on trust or failed to recognise. Hawks makes this point overtly, and fairly unsubtly, when Maya, one of a resistance group known as Harlequins, reprises her father's argument that $99 \%$ of people are 'citizens or drones' (8). The former 'think they understand what's going on in the world,' while the latter are 'so overwhelmed by the challenge of surviving that they are unaware of anything outside their day-to-day lives.' 'The facts you know,' she tells her psychiatrist, 'are mostly an illusion. The real struggle of history is going on beneath the surface' (9). Provoking the average reader (who might recognise themselves as a citizen rather than a drone) to an awareness of underlying and integrates surveillance mechanisms and policies, Hawks uses elements from the thriller, the political novel, martial arts films and conspiracy theory to fashion a fast-paced and highly readable account of existing and emerging trends in surveillance.

The Traveller integrates these aesthetic components with aspects of real world or plausibly real world surveillance, noting the high number of CCTV cameras in Britain, how anti-terrorism laws allow the expansion of their reach, and how 'an average person working in London would be photographed by three hundred different surveillance 
cameras during the day' (70). Facial recognition systems are explained when Maya needs to avoid detection moving from country to country (74), as is the Carnivore internet surveillance programme (163). The Terrorism Information Awareness system introduced in the United States is considered (178), and the United States and Australian governments are said to have embedded 'radio frequency ID chips' in the covers of passports. A projected but failed attempt to introduce a Protective Link, or PL Device is also depicted:

Coded in a certain way, the PL device could be a universal credit card and debit card. It could access all your medical information in case you were in an accident. If all loyal, law-abiding Americans wore a PL device, street crime could disappear within a few years. In one magazine ad, two young parents wearing PL devices tucked in a sleeping daughter whose Protective Link ID card was being held by her teddy bear. The ad slogan was simple but effective: 'Fighting Terrorism While You Sleep' (Hawks, 2005: 106). By incorporating actual surveillance technology and practices with possible advances in these realms, The Traveller constructs a plausible world in which an alternative reality exists, beneath, above, or parallel to that normally experienced or understood by the reader.

The generic code requires a counter narrative, and in The Traveller several different types of resistant characters are developed. The first we meet is Maya, who, like her father, is a Harlequin, a group sworn to protect the 'travellers' of the title. This aspect of the novel, though clearly central, delves into more esoteric or fantastic matters, moving well away from the every day. Travellers are quasi-mystical figures able to move between various realms of existence, of which this world is only one. They are figures, who, when the return to the 'real' world, activate massive cultural and spiritual renewal; it is suggested, but never confirmed, that Travellers in the past might have included Jesus, Muhammad, Buddha 'or an obscure Hasidic rabbi who was killed in the Holocaust' (185). Despite the assumption that there are no Travellers left in the modern world, the result of them being killed off by the Brethren, Maya finds out that two brothers are thought to be potential candidates. The Brethren also have this information, and set out to capture rather than kill the brothers. Here surveillance meets science fiction and ersatz mysticism. The Brethren intend to create a Virtual Panopticon that will completely dominate the world's population, instituting what for them is a utopian world of stasis, passivity and control. In order to fast-track this process, they aim to utilise the knowledge of an advanced alien civilisation, and, as compensation, need to employ a Traveller to guide that civilisation, who wish to visit Earth. Clearly, in this manoeuvre, Hawks vigorously relocates the reader from something like the real world to the undeniably fantastic. But while the move requires a massive suspension of disbelief, it maintains the generic pattern of the dystopia in creating cognitive estrangement. And it sets up a dynamic between utopian and dystopian possibilities, for while both of the brothers are discovered to be Travellers, predictably perhaps, one is willing to work for The Brethren, one against. They embody the struggle between utopian freedom and change and the dystopian desire for rigidity and control. The novel ends with those possibilities still not actualised, for The Traveller is revealed on the last page as only the first part of a literary series.

This lack of resolution, and the need, therefore, that readers buy the next in the series to keep up with the complexities and intrigues of the plot, has led some critics to see the work as a highly manipulative attempt to fashion a publishing phenomenon. Their 
suspicion can only be heightened given that the editor of The Traveller also edited The Da Vinci Code. But while Dan Brown did much to promote and defend his blockbuster, John Twelve Hawks (a pseudonym) has refused interviews, and indeed (if the publishers are to be believed) has had no physical contact with them. He (or she) is said to live, in the terms of the books, 'off the Grid', without credit or identity cards, traceable location, or land line telephone access. This could also, of course, be part of a marketing ploy, although the publishers insist that this is not the case. But in terms of surveillance and its place in modern culture, the provocative thing about Twelve Hawks' strategy is that it presents him or her as a resistant figure to the system the novel assures us is all around. While playing on surveillance suspicions and fears, Twelve Hawks also uses those fears to create an arresting mystique that folds back into the book's message of mainstream passivity and complicity with the Vast Machine. While depicting and critically assessing surveillance, then novel's author simultaneously subverts it.

\section{Conclusion}

In many ways, The Traveller taps into fears and scenarios similar to those evoked by George Orwell more than half a century ago in Nineteen Eighty-Four. But as this analysis of that novel and some recent films has shown, the fictional depiction of surveillance in recent years has moved substantially beyond Orwellian notions, incorporating not only the more obvious elements such as new technology, but also offering a variety of complex and nuanced accounts that range over entertainment, genetic scrutiny, new forms of access or exclusion, and the use of social sorting to create societal and cultural hierarchies. They have delved into such areas as terrorism, body screening, government and corporate surveillance, and the effect of surveillance on those undertaking the surveillance, not simply those under scrutiny. They chart resistance to, as well as complicity with, different forms of surveillance regime. Collectively, these recent works reflect how notions of surveillance have infiltrated the public imagination, while at the same time they themselves have no doubt influenced how the public perceives surveillance. And while social theorists and researchers might see deficiencies or biases in these portraits of imagined surveillance societies, it remains true that the public is far more likely to gain its understanding of surveillance from fiction rather than from academic studies. Many more people read Orwell than read Foucault.

I have argued that dystopian texts in general function to prompt thinking, rather than to limit it. The cognitive estrangement built into such texts ensures active reader participation in the creation of meaning. By offering readers and viewers imaginative and provocative accounts of alternative places, that draw from, heighten, or extrapolate currents fears, trends and circumstances, they also offer yardsticks by which to measure how we live now, and where we as individuals and societies are heading. These projected worlds create spaces for mental experiments, allowing us to consider novel moral, political and philosophical problems and scenarios. From this speculation, and reflection, as Nussbaum reminds us, practical action can be generated. Rather than reducing their audiences to passivity and pessimism, such texts have a built-in counter narrative that can inspire us to question and resist the negative trends while critically assessing any changes presented as positive. This informed scepticism is vital in a contemporary world where the reference points of acceptable and unacceptable surveillance are highly fluid. 
As a genre interested in emerging trends, utopias in the broadest sense offer not only an understanding of past depictions of surveillance, but also speculations on the ways surveillance might develop in the future. This openness to possibilities seems appropriate today given that recent technological, social and political changes have meant that surveillance studies itself has become an increasingly speculative and adaptive field. David Lyon provides a textual manifestation of this adaptation in Surveillance After September 11 (2003). In the Introduction he states:

When I planned this book I had entitled the last chapter 'Rethinking Surveillance,' but the process of researching and writing obliged me to rethink the title itself. I have now called it 'Resisting Surveillance' because I have been struck the more forcibly by the fact that the changes described are so far-reaching, retrograde, even reprehensible (Lyon, 2003: 10-11).

He begins the first chapter with a quotation from Jacques Ellul about the drive towards total surveillance (13), and ends the study as a whole with Ellul's vision of 'a city whose gates are never shut. It is a place of inclusion and trust. And its light finally banishes all that is now dark in the world' (166). There is a clear, if unconscious, move from a dystopian to a utopian vision in Lyon's use of Ellul. He also notes an important parallel between the September 11 attacks and the surveillance response to those attacks that so disturb him; each has 'a complex but clear context and an historical background' (14) Lyon adds that 'Jacques Ellul already noted the development of surveillance societies back in the 1960s and Orwell had inklings back in the 1940s!' (14). I have suggested in this article that the utopian genre offers a rich and rewarding body of work for studying surveillance concerns and depictions well before Orwell, at least as far back as Thomas More. Yet, while the generic continuity offers a means of usefully comparing similarities over the centuries, it also allows for analysis of differences, especially since Orwell. The texts considered in this article in no way exhaust the list of recent dystopian accounts of surveillance; JG.Ballard's Super-Cannes (2001), Steven Spielberg's Minority Report (2003), along with Wachowskil and Wachowski's The Matrix Trilogy (1999-2003) and Proyas' I, Robot (2004) immediately spring to mind. Lists from other fictional genres might as easily be drawn up. But, as this article has attempted to show, utopias offer particularly fertile territory for investigation. Indeed, Lyon's use of Ellul underlines the value of utopias generically in considering surveillance in its widest implications, whether as a means of understanding the negatives, or of striving for the positives. In a world where the scope and reach of surveillance is rapidly changing, along with the arguments and motivations for those utilising and resisting it, the utopian genre gives us ways of understanding how inventive minds have depicted and assessed surveillance in the past, and continue to formulate new understanding in the light of present circumstances. They also allow us to speculate intelligently about its future course, providing ways of dealing successfully with, as H.G. Wells memorably put it, the shape of things to come. 


\section{References}

Baccolini, R. and Moylan, T. (2003) 'Dystopias and Histories'. In Baccolini, R. and Moylan, T. (eds.) Dark Horizons: Science Fiction and The Dystopian Imagination. New York, Routledge.

Ballard, J.G. (2001) Super-Cannes. London, Flamingo.

Booker, M. (1994) Dystopian Literature: A Theory and Research Guide. Westport, Connecticut, Greenwood Press.

Claeys, G. and Sargent, L. (eds.) (1999) The Utopian Reader. New York, New York University Press.

Cohen, S. (1985) Visions of Social Control. Cambridge, Polity Press.

Goold, B. (2004) CCTV and Policing: Public Surveillance and Police Practices in Britain. Oxford, Oxford University Press.

Foucault, M (1977) Discipine and Punish Harmondsworth, Penguin

Foucault, M (1973) The Birth of the Clinic: An Archaeology of Clinical Perception London.

Hawks, J. (2005) The Traveller. London, Bantam Press.

Huxley, A. (1994) Brave New World. London, Flamingo.

Jameson, F. (1988) The Ideologies of Theory. Essays 1971-1986. Volume 2: The Syntax of History. London, Routledge.

Lyon, D. (1994) The Electronic Eye: The Rise of Surveillance Society. Cambridge, Polity Press.

Lyon, D. (2001) Surveillance Society: Monitoring Everyday Life. Buckingham, Open University Press.

Lyon, D. (2003) Surveillance After September 11. Cambridge, Polity Press.

More, T. (1989) Utopia. (eds. G.M. Logan and R.M. Adams). Cambridge, Cambridge University Press.

Moylan, T. (1986) Demand the Impossible: Science Fiction and the Utopian Imagination. New York, Methuen.

Niccol, A. (1997) Gattaca. Columbia Pictures

Nussbaum, M. (1990) Love's Knowledge: Essays on Philosophy and Literature. New York, Oxford University Press.

Orwell, G. (1997) Nineteen Eighty-Four. London, Secker and Warburg.

Proyas, A. (2004) (dir.) I, Robot. $20^{\text {th }}$ Century Fox.

Poudrier, J. (2003) 'Racial' Categories and Health Risks: Epidemiological Surveillance Amongst Canadian First Nations'. In Lyon, D. (ed.) Surveillance as Social Sorting: Privacy, Risk and Digital Discrimination. London, Routledge.

Rorty, R. (1989) Contingency, Irony, and Solidarity. Cambridge, Cambridge University Press

Rule, J. (1973) Private Lives and Public Surveillance. London, Allen Lane.

Sargent, L. (2001) US Eutopias in the 1980s and 1990s: Self-Fashioning a World of Multiple Identities. In 
Spinozzi, P. (ed.) Utopianism/Literary Utopias and national Cultural Identities: A Comparative Perspective. Bolognia, COTEPRA/University of Bolognia.

Spielberg, S. (2003) (dir.) Minority Report. Dreamworks SKG.

Suvin, D. (1979) Metamorphoses of Science Fiction: On the Poetics and History of a Literary Genre. New Haven, Yale University Press.

Torpey, J. (2000) The Invention of the Passport: Surveillance, Citizenship and the State. Cambridge, Cambridge University Press.

Wachowksi, A and Wachowski L. (1999) (dirs) The Matrix. Groucho II Film Partnership, Silver Pictures, Village Roadshow Pictures.

Wachowksi, A and Wachowski L. (2003) (dirs) The Matrix Reloaded. Warner Brothers, Silver Pictures, NPV Entertainment, Village Roadshow Pictures.

Wachowksi, A and Wachowski L. (2003) (dirs) The Matrix Revolutions. Warner Brothers, Silver Pictures, NPV Entertainment, Village Roadshow Pictures.

Weir, P. (1998) (dir.) The Truman Show. Paramount.

Whitebrook, M. (1996) Taking the narrative turn: what the novel has to offer political theory. Literature and the Political Imagination. J. Horton and A. Baumeister (eds.) London, Routledge: 32-52.

Winterbottom, M. (2003) (dir.) Code 46. BBC and Revolution Films. 